\title{
Intellectual capital-enhancing HR, Absorptive Capacity and Innovation
}

\author{
Christine Soo \\ Business School, the University of Western Australia, Perth, Western Australia \\ Email: Christine.Soo@uwa.edu.au
}

\author{
Amy Wei Tian \\ Business School, the University of Western Australia, Perth, Western Australia \\ Email: amy.tian@uwa.edu.au \\ Stephen Teo \\ AUT Business School, AUT University, Auckland, New Zealand \\ Email: stephen.teo@aut.ac.nz \\ John L. Cordery \\ Business School, the University of Western Australia, Perth, Western Australia \\ Email: john.cordery@uwa.edu.au
}




\title{
Intellectual capital-enhancing HR, Absorptive Capacity and Innovation
}

\begin{abstract}
This study investigates the role of intellectual capital (i.e., human, social and organization capital) enhancing HR practices in the development of a firm's potential and realized absorptive capacity, as well as the impact of absorptive capacity on the firm's innovative performance. Results show that while human capital enhancing HR (acquisition and developmental HR) is positively related to potential absorptive capacity, social capital enhancing HR impacts on potential absorptive capacity through egalitarian practices and realized absorptive capacity through collaborative practices. Organization capital enhancing HR practices also play a role in both dimensions of absorptive capacity. Finally, our findings confirm that innovative performance is driven only by realized absorptive capacity.
\end{abstract}

\section{Keywords:}

Strategic HRM, strategy, learning organisations, knowledge management or transfer, intellectual capital

\section{INTRODUCTION}

The literature on absorptive capacity has obtained a wealth of theoretical perspectives as well as empirical evidences regarding its antecedents and consequences. Intellectual capital (IC) and human resource management (HRM) practices have been identified as key factors to facilitate the firm's absorptive capacity (i.e. Hitt, Bierman, Shimizu, \& Kochhar, 2001; Lepak \& Snell, 1999). However, recent reviews (i.e. Lewin et al., 2011; Volberda et al., 2010:932) have highlighted that there continues to be a lack of HRM-related research in the absorptive capacity-related areas. Furthermore, research has not simultaneously investigated the effect of the two key factors (IC and HRM practices) upon firms' organisational absorptive capacity. Thus, in the development of our conceptual model, we bring together the literatures on absorptive capacity, IC and strategic HRM. This paper examines the role of IC-enhancing human resource (HR) configurations as contributing factors towards the development of absorptive capacity in organisations. As distinct from previous studies linking human resource management (HRM) and knowledge transfer, we propose IC-enhancing HR configurations as direct contributing factors rather than exogenous to the creation and development of absorptive capacity. Theoretically, we bring together research from the knowledge transfer, IC, and strategic HRM fields, and seek to understand (1) the role of IC-enhancing HR configurations as distinct organisational 
antecedents that enhance the creation and development of a firm's absorptive capacity, and (2) the role of absorptive capacity in contributing towards a firm's innovative performance.

\section{THEORETICAL FRAMEWORK AND HYPOTHESES}

\section{Absorptive capacity}

Starting from the seminal work of Cohen and Levinthal, absorptive capacity is defined as the "ability of the firm to recognize the value of new, external information, assimilate it, and apply it to commercial ends" (1990: 128). Researchers have shown that the development of absorptive capacity contributes towards innovation (Lichtenthaler, 2009; Tsai, 2001), financial performance (Kostopoulos, Papalexandris, Papachroni, \& Ioannou, 2011), intra-organisational knowledge transfer (Szulanski, 1996), and inter-organisational learning (Lane \& Lubatkin, 1998; Lane, Salk, \& Lyles, 2001). Central to the firm's ability to realize performance improvements from external knowledge sources are four distinct but complementary learning capabilities as outlined by Zahra and George (2002) - acquisition (the ability to identify and acquire critical knowledge), assimilation (the ability to analyse, process, interpret and understand external knowledge), transformation (the ability to combine new and existing knowledge to gain new insights and perspectives), and exploitation (the ability to incorporate the newly acquired and transformed knowledge into the firm's operations). Zahra and George (2002) argue that acquisition and assimilation capabilities form a firm's potential absorptive capacity (i.e., PACAP), while its transformation and exploitation capabilities are part of its realized absorptive capacity (i.e., RACAP).

However, despite the size and richness of the literature on absorptive capacity, recent research has pointed out that the construct is taken for granted and little attention has been devoted to understand how absorptive capacity is created and developed within the firm (Lane, Koka, \& Pathak, 2006; Minbaeva, Pedersen, Bjoerkman, Fey, \& Park, 2003). To address these limitations and advance our understanding of absorptive capacity, Volberda, Foss and Lyles (2010) has highlighted the major discrepancies in the field. In particular, the authors argue that "absorptive capacity has an important, but hitherto neglected, set of distinctly organisational antecedents, such as organisational structure, reward systems, and systems of HRM practices and policies" (Volberda et al., 2010:932). In the same vein, another recent paper by Lewin, Massini and Peeters (2011) draws attention to the routine 
structure underlying absorptive capacity and they decompose the construct of absorptive capacity into two components, internal and external absorptive capacity capabilities. The authors indicate that one "limitation of the extant literature and research on absorptive capacity is that it overlooks the internal dimension of absorptive capacity as enabling companies to initiate change from within" (Lewin et al., 2011:85). They refer internal absorptive capacity capabilities as the management of the processes of internal variation, selection, and replication (Lewin et al., 2011). This brings issues such as hiring practices, reward systems, and other aspects of HRM into the picture.

This neglected perspective is surprising, since Cohen and Levinthal $(1989,1990)$ were quite explicit that the organisational mechanisms are important and distinctive (Jansen, Van Den Bosch, \& Volberda, 2005). Nevertheless, a few exemptions have attempted to investigate the relationship between specific HRM practices and absorptive capacity. For example, Jansen et al. (2005) concluded that job rotation and participation enhance potential absorptive capacity. Furthermore, Minbaeva and her colleagues have integrated the research on knowledge transfer and HRM to better understand how HRM influences a firm's absorptive capacity (i.e., Minbaeva, 2005; Minbaeva et al., 2003). Individual HR practices such as staffing, training, performance appraisal, compensation and job rotation, and the like, all prove instrumental for enhancing knowledge transfer (Jansen et al., 2005; Laursen \& Foss, 2003; Minbaeva, 2005; Minbaeva et al., 2003; Simonin \& Özsomer, 2009). Nevertheless, the authors suggest that "... a good deal more work needs to be done to uncover the underlying mechanisms by which HR practices influence the development of knowledge” (Minbaeva, Foss, \& Snell, 2009:478).

\section{Intellectual Capital Enhancing HRM and Absorptive capacity}

Intellectual capital (IC) is defined as 'the sum of all knowledge an organisation is able to leverage in the process of conducting business to gain competitive advantage" (Youndt, Subramaniam, \& Snell, 2004:337). It is classified as a multidimensional entity, formed by three basic types of capital: human, social, and organisational capital (Subramaniam \& Youndt, 2005). Scholars have suggested that each components of IC plays a distinctive role in the knowledge transfer process by developing, sharing, and integrating individual knowledge into organisational knowledge (Kang \& Snell, 2009). Empirically, research has demonstrated how various HRM practices could be combined to support the 
development of human, social and organisational capital separately (i.e., Lepak \& Snell, 1999; Youndt \& Snell, 2004; Youndt et al., 2004).

In the development of our conceptual model, we bring together the literatures on absorptive capacity, IC and strategic HRM. As highlighted by recent reviews (i.e. Lewin et al., 2011; Volberda et al., 2010:932), there continues to be a lack of HRM-related research in the absorptive capacity. Current studies have largely considered HRM practices exogenous to the creation and development of absorptive capacity. To the best of our knowledge, no previous study has examined the role of ICenhancing HR configurations in relation to knowledge strategy and absorptive capacity. Building on the view that HR practices are "instrumental for enhancing the flow of knowledge - that is, its acquisition, transfer and integration within the organization”, (Minbaeva et al., 2009: 478), we propose that IC-enhancing HRM practices will leverage the four processes of absorptive capacity (i.e., acquisition, assimilation, transformation and exploitation) within a firm. In addition, previous research on the relationship between HRM and absorptive capacity has largely focused on the impact of individual HRM practices in isolation, such as training and recruitment (i.e., Minbaeva et al., 2003). On the other hand, research on HRM and IC has taken a more holistic approach by developing configurations of multiple HR activities such as human capital, social capital and organisational capital enhancing HR systems (i.e., Youndt $\&$ Snell, 2004). It is in this context that we integrate two previously separate fields of research by introducing the concept of IC-enhancing HR configurations into absorptive capacity research. Specifically, we integrate the work on HR architecture/configuration by Lepak and Snell (2002) and Youndt and Snell (2004) in our proposed model (Figure 1) by examining the role of human, social and organisational capital enhancing HR on both potential (acquisition and assimilation) and realized (transformation and exploitation) absorptive capacity.

Insert Figure 1 about here

\section{The Role of Human Capital Enhancing HR Configurations}

Youndt and Snell (2004) outline two forms of human capital enhancing HR configurations acquisition and developmental. The first relates to the "buying" human capital (e.g., selective staffing, 
compensation and rewards system to attract the best candidates), and the latter relates to "making" human capital (i.e. comprehensive training practices, promotion-from-within, developmental performance processes, skill-based pay). We argue that the presence of such HR practices plays a significant role in better equipping the organisation to acquire and assimilate new knowledge (i.e., potential absorptive capacity). Acquiring and developing a firm's human capital represents a direct link to its ability to understanding, interpret and absorb new external knowledge. We hypothesize that:

Hypothesis 1a: An acquisition HR configuration will be positively related to an organisation's potential absorptive capacity.

Hypothesis 1b: A developmental HR configuration will be positively related to an organisation's potential absorptive capacity.

\section{The Role of Social Capital Enhancing HR Configurations}

Youndt and Snell (2004) outline two forms of social capital enhancing HR configurations - egalitarian and collaborative. The first relates to eliminating vertical barriers through practices that eliminate status symbols, reduce hierarchical levels and minimize job classifications. The second relates to eliminating horizontal barriers by encouraging social networks and collaborations through the use of team development practices and group incentives. Building on Brown and Duguid's (2001) arguments that organisational knowledge is acquired, shared and applied predominantly through the social practices of its members, we hypothesize HR configurations that enhances an organisation's social capital contributes significantly to both its potential and realized absorptive capacity.

Hypothesis 2a: An egalitarian HR configuration will be positively related to an organisation's potential absorptive capacity.

Hypothesis 2b: An egalitarian HR configuration will be positively related to an organisation's realized absorptive capacity.

Hypothesis 3a: A collaborative HR configuration will be positively related to an organisation's potential absorptive capacity.

Hypothesis 3b: A collaborative HR configuration will be positively related to an organisation's realized absorptive capacity. 


\section{The Role of Organisational Capital Enhancing HR Configurations}

The final set of HR configurations is related to the organisation's ability to capture, document, and store its information and knowledge flows. Youndt and Snell's (2004) organisational capital enhancing HR configurations consists of documentation (i.e., institutionalizing knowledge in databases, manuals, and standard operating procedures) and information technology (i.e., systems that are accessible, user-friendly and integrated). It can be argued that organisational capital not only establishes patterns of behaviour and interpretation systems that guide knowledge acquisition, it is also a mechanism for integrating and combining that knowledge into organisational knowledge (Kang \& Snell, 2009). Thus, we hypothesize a positive relationship between organisational capital HR configurations and both potential and realized absorptive capacity:

Hypothesis 4a: A documentation HR configuration will be positively related to an organisation's potential absorptive capacity.

Hypothesis 4b: A documentation HR configuration will be positively related to an organisation's realized absorptive capacity.

Hypothesis 5a: An information technology HR configuration will be positively related to an organisation's potential absorptive capacity.

Hypothesis 5b: An information technology HR configuration will be positively related to an organisation's realized absorptive capacity.

\section{Potential and Realized Absorptive Capacity}

Although potential and realized absorptive capacity are conceptualized as two distinct dimensions by Zahra and George (2002), there exists a strong theoretical relationship between them. Specifically, in order for firms to transform and exploit new knowledge (to generate performance), they must first have the capabilities to acquire and assimilate them previously. Hence, we hypothesize a positive relationship between the two dimensions of absorptive capacity:

Hypothesis 6: There is a positive relationship between potential and realized absorptive capacity.

\section{Absorptive Capacity and Innovation}

Building on previous studies (i.e., Kostopoulos et al., 2010; Lichtenthaler, 2009; Tsai, 2001), we argue that a firm's absorptive capacity is a strong contribution factor towards its innovative performance. 
However, we argue that the impact on innovation is only through realized absorptive capacity, rather than potential absorptive capacity. Zahra and George (2002: 191) assert this distinction very clearly 'a high PACAP does not necessarily imply enhanced performance. RACAP involves transforming and exploiting the assimilated knowledge by incorporating it into the firm's operations, thereby improving its performance....Despite the importance of PACAP, RACAP is the primary source of performance improvements'. Hence, we hypothesize the following relationships:

Hypothesis 7: There is no significant relationship between potential absorptive capacity and innovation.

Hypothesis 8: There is a positive relationship between realized absorptive capacity and innovation.

\section{METHODS}

\section{Sample and Data Collection Procedures}

The sample for this study consisted of 1842 firms which were randomly selected from a member list provided by our research partner, the Australian Institute of Management - Western Australian (AIMWA). The sample includes firms from a wide variety of industries and sizes, thus contributing to the generalizability of the study's findings. An online questionnaire was sent via email to senior managers who were considered (by their positions) to have adequate knowledge about their organisation's HRM policies and practices, learning activities and innovation performance within their firms. A cover letter explained the objective of the survey and assured respondents of the confidentiality of their responses and the voluntary nature of their participation.

A total of 252 firms responded to the questionnaire, which gave a response rate of $13.7 \%$ of the total original sample population. Given the low response associated with online surveys, this response rate was considered reasonably adequate. Among the returned questionnaires, 31 questionnaires were discarded as they were considered incomplete (i.e., more than $30 \%$ missing data). Thus, a total of 221 usable questionnaires were retained for data analysis, giving an effective response rate of $12 \%$.

A wide variety of industries types were captured in this study, including mining and construction sector $(21.3 \%)$ and government bodies and not-for-profit $(21.3 \%)$, health and social work (19\%), property $(10.9 \%)$, financial intermediation and personal $(7.8 \%)$, manufactory $(4.1 \%)$, transportation 
(4.1\%), cultural and education (5.9\%), and wholesale and retail trade (3.2\%). Majority of the firms have been operating for more than 20 years (i.e., $71.5 \%$ ); $19.3 \%$ were in operation between 10-20 years; and $9.2 \%$ less than 10 years. Regarding the size of the firms, the sample represents a reasonably even distribution: $23.2 \%$ had more than 2000 employees, $24.6 \%$ had between 500-2000 employees, $30.9 \%$ had $100-500$ employees, and $21.3 \%$ had less than 100 employees.

We also gathered the demographic information about the respondents. The final sample consisted of 46.3 per cent female, 38.4 per cent was in top senior management (i.e., CEOs, Directors and General Managers) and 31.7 per cent was HR and Training decision makers. The final sample's mean tenure within their current job, their organisation and their industry were 4.3 years, 7.4 years and 14.7 years, respectively.

\section{Pilot Test}

Although our measures were developed from those previously established in the literature, we wanted to ensure that they were appropriate for our study sample. A preliminary online survey was conducted to make sure that every question was phrased appropriately so that respondents could clearly understand each concept and answer each question. The pilot-test was conducted on 31 WA-based companies. Based on the respondents' feedback, a few questions were amended accordingly.

\section{Measures}

\section{HR Configurations}

We drew upon Youndt and Snell's (2004) HR Configurations and Lepak and Snell's (2002) HR Architecture and developed 41 items to measure six distinctive HR configurations focused on building human capital (i.e., acquisition and developmental HR), social capital (i.e., egalitarian and collaborative HR), and organisation capital (i.e., documentation and information technology HR). Consistent with the approach used by Youndt and Snell (2004) and Lepak and Snell (2002), each of the six HR configurations were conceptualised as a summative index and within the path model, these were operationalized as second order latent variables.

Acquisition and development items both concerned a firm's HR activities which aim to enhance its human capital. The six-item acquisition items focused attracting the best candidate through recruitment practices as well as compensation and reward aspects. The eleven-item developmental 
scale was related to a firm's HR activities which enhanced their human capital through training, developmental performance appraisal as well as compensation for knowledge and skills.

Egalitarian and collaborative scale both concerned a firm's HR activities which contributed to eliminating vertical as well as horizontal barriers to its social capital. The five-item egalitarian scale concerned HR activities which may help to reduce vertical barrier by the elimination of hierarchical levels and job classifications. The ten-item collaborative scale concerned HR activities which help to eliminating horizontal barrier to a firm's social capital through the development of collaborations and teamwork.

Documentation and information scale concerned a firm's HR activities which contributed to the development of organisational capital. A total of 11 items were adapted from Youndt and Snell (2004) and Ravichandran and Lertwongsatien (2005). The four-item documentation scale measured HR activities which may help to better codify both explicit and tacit knowledge within the firm. Seven items were used to measure a firm's information technology HR configuration. The information scale concerned HR activities that support knowledge management and codification within the firm.

Absorptive capacity

We developed 24 items measuring the four dimensions of a firm's absorptive capacity (i.e., acquisition, assimilation, transformation and exploitation) by adapting measures from Jansen et al. (2005), Lichtenthaler (2009), and Flatten, Engelen, Zahra and Brettel (2011). The five-item acquisition scale assessed an organisation's ability to identify and obtain new knowledge from external sources. The six-item assimilation scale assessed an organisation's ability to develop processes and routines useful in analysing, interpreting, and understanding newly acquired external knowledge (Zahra \& George, 2002). The six-item scale transformation measured the extent to which organisations were able to develop routines to facilitate the combination of existing knowledge with the newly acquired and assimilated knowledge to form new knowledge or insights. The seven-item exploitation scale assessed the extent to which organisations were able to apply and exploit new external knowledge to produce new or improved products, services or processes.

We developed the two dimensions of absorptive capacity as reflective second order latent variables. Drawing upon Zahra and George's (2002) conceptualizations, potential absorptive capacity is 
measured by the acquisition and assimilation scale, while realized absorptive capacity is measured by the transformation and exploitation scale. The composite reliability coefficient was 0.91 for potential absorptive capacity, and 0.93 for realized absorptive capacity.

\section{Innovation Performance}

Innovation performance was measured in two dimensions, incremental innovation and radical innovation, using the six items for each scale developed by Gatignon, Tushman, Smith and Anderson (2002). The incremental innovation scale assessed a firm's capability to develop products, services and processes that were competence enhancing, i.e., to reinforce and extend its current expertise. The Cronbach alpha for these items was 0.94 . The radical innovation scale measured a firm's capability to develop products, services and processes that were competence destroying, i.e., making its current expertise obsolete. The Cronbach alpha for these items was 0.68. Innovation performance was operationalized as a second order reflective scale. It has a composite reliability coefficient of 0.80 .

All items developed in this study utilized a response scale from 1 (not at all or strongly disagree) to 5 (to a great extent or strongly agree), and are listed in Table 1.

\section{Insert Table 1 about here}

\section{Method of Analysis}

We used the SmartPLS v2.0.M3 (Ringle, Wende, \& Will, 2005) software to analyse the data. Survey data were initially entered into PAWS v.19 for preliminary analysis including exploratory factor analysis and calculation of means, standard deviations and correlations. There were eight independent constructs and one dependent construct in the path model. The sample size of 221 cases is considered to be sufficient to achieve a medium effect size of 0.80 (Green, 1991: 503). Bootstrapping was conducted with 500 sub-samples to ensure that the results were not sample-specific. We tested for the effect of common method bias by conducting Harman's ex-post one factor test (Podsakoff \& Organ, 1986). All variables were entered into an unrotated factor analysis, which showed that there were nine factors with eigenvalues greater than 1.0, with the largest single factor explained $37 \%$ of the variance. Confirmation of the reflective scales was undertaken by conducting a discriminant validity. The analysis required the computation of the square root of the average variance estimates (AVEs) and 
comparison of this index with the correlation with the other constructs in the path model (Fornell \& Larcker, 1981). Results are reported together with the descriptive statistics in Table 2. Predictive relevance was determined by computing the Stone-Geisser Q-square test (Chin, 2010) in the SmartPLS software. The global criterion for goodness of fit (Tenenhaus, Vinzi, Chatelin, \& Lauro, 2005) was also computed to determine the extent to which the model's goodness of fit. Based on our calculations, we were confident that the model is stable and the predictive relevance requirement is satisfied.

\section{RESULTS}

Results of the path analysis are reported in Table 3. With the exception of hypotheses $2 b, 3 a$ and $4 b$, all of the remaining hypotheses were supported. For example, the results for six dimensions of HR and Potential $A C$ are shown in Table 3. The coefficient for Acquisition $H R(\beta=.20, \mathrm{p}<.01)$, Developmental HR $(\beta=, .17, \mathrm{p}<.05)$, Egalitarian HR $(\beta=.14, \mathrm{p}<.05)$, Documentation HR $(\beta=.16$, $\mathrm{p}<.05)$, IT HR $(\beta=.21, \mathrm{p}<.001)$ were all significant, indicating these dimensions of HR are significant predictors of organisations' Potential AC. However, Collaborative HR was not found to be a significant predictor of Potential $A C(\beta=.07)$. The model demonstrated a high level goodness of fit, as indicated by Tenenhaus et al.'s (2005) global goodness of fit index (0.62). R-square of the dependent variable, Innovation Performance, is 0.25 .

Insert Tables 2 and 3 about here

\section{DISCUSSION}

The objectives of this study were (1) to investigate the role of IC-enhancing HR configurations as contributing factors towards a firm's potential (i.e., acquisition and assimilation) and realized (i.e., transformation and exploitation) absorptive capacity, and (2) to illustrate the role of absorptive capacity in contributing towards a firm's innovative performance. Our study contributes to absorptive capacity research in two major directions: first, it integrates previously separate sets of literature on HRM practices, intellectual capital and absorptive capacity. That is, we investigated important underlying internal organisational antecedents of absorptive capacity, an often neglected area of research (Lewin et al., 2011; Volberda et al., 2010). Second, by extending the current research on 
HRM and intellectual capital, we identified specific HRM practices that managers might implement to develop different dimensions of the firm's IC (human capital, social capital and organisational capital), as well as absorptive capacity. In particular, our results offer numerous insights into how targeted HR investments may contribute to different dimensions of an organisation's absorptive capacity. For example, human capital enhancing HR practices (in the form of recruiting and developing talent) has a positive influence on the firm's ability to acquire and assimilate new external knowledge. With regards to social capital enhancing HR practices, the use of egalitarian HR practices has more impact on the acquisition and assimilation of new knowledge, but having collaborative HR practices is crucial in ensuring that the new knowledge is effectively exploited and applied into new products, services and/or processes. This result resonates with Jansen, van den Bosch and Volberda's (2005) findings that a firm's socialization capabilities play a significant role in its realized absorptive capacity. Finally, the role of organization capital enhancing HR practices is also important. The presence of an effective IT system is important for both dimensions of absorptive capacity. These results suggesting that HR practices aim to encourage knowledge capture and documentation play a more significant role in potential rather than realized absorptive capacity, suggesting that the transformation and exploitation of new knowledge is influenced predominantly by an organization's social capital. These results present major implications for practitioners by offering new insights into the differential roles played by different forms of HR practices. While it is important for the firm to engage in human capital enhancing HR practices to develop capabilities for new knowledge acquisition and assimilation, in order to take it a step further in terms of exploiting that knowledge for performance improvements, both social and organization capital enhancing HR practices are crucial.

With regards to the relationship between absorptive capacity and innovative performance, our results further confirm Zahra and George's (2002) argument that performance improvement is largely driven by a firm's realized absorptive capacity. Again, the managerial implications from this finding are significant as it clearly suggests that developing capabilities for knowledge acquisition and assimilation is only one side of the story. In order to generate performance improvements, managers need to develop the appropriate collaborative structures and mechanisms (supported by an effective IT system) that will generate capabilities to effectively transform and exploit the new knowledge. 


\section{REFERENCES}

Brown JS and Duguid P (2001) Knowledge and organization: A social-practice perspective. Organization Science 12:198-213.

Chin WW (2010) How to write up and report PLS analyses, in Chin WW (Eds.) Handbook of Partial Least Squares Analysis: Concepts, Methods and Applications, pp. 645-688, Springer, Berlin Heidelberg

Cohen WM and Levinthal DA (1989) Innovation and learning: the two faces of R \& D, The Economic Journal 99:569-596.

Cohen WM and Levinthal DA (1990) Absorptive capacity: A new perspective on learning and innovation, Administrative Science Quarterly 35:128-152.

Flatten TC, Engelen A, Zahra SA and Brettel M (2011) A measure of absorptive capacity: Scale development and validation, European Management Journal 29: 98-116.

Fornell C and Larcker DF (1981) Evaluating structural equation models with unobservable variables and measurement error, Journal of Marketing Research 18:39-50.

Gatignon H, Tushman ML, Smith W and Anderson P (2002) A structural approach to assessing innovation: Construct development of innovation locus, type, and characteristics, Management Science 48:1103-1122.

Green SB (1991). How many subjects does it take to so a regression analysis? Multivariate Behavioral Research 26:499-510.

Hitt MA, Bierman L, Shimizu K and Kochhar R (2001) Direct and moderating effects of human capital on strategy and performance in professional service firms: A resource-based perspective, Academy of Management Journal 44:13-28.

Jansen JJP, Van Den Bosch FAJ. Volberda HW (2005) Managing potential and realized absorptive capacity: How do organizational antecedents matter? Academy of Management Journal, 48:999-1016

Jansen JJP, Van Den Bosch FAJ and Volberda HW (2006) Exploratory innovation, exploitative innovation and performance: Effects of organizational antecedents and environmental moderators, Management Science 52:1661-1674.

Kang SC and Snell SA (2009) Intellectual capital architectures and ambidextrous learning: a framework for human resource management, Journal of Management Studies 46:65-92.

Kostopoulos K, Papalexandris A, Papachroni M and Ioannou G (2011) Absorptive capacity, innovation, and financial performance Journal of Business Research, 64:1335-1343.

Lane PJ, Koka BR and Pathak S (2006) The reification of absorptive capacity: A critical review and rejuvenation of the construct, Academy of Management Review 31:833-863.

Lane PJ and Lubatkin M (1998) Relative absorptive capacity and interorganizational learning, 
Strategic Management Journal 19: 461-477.

Lane PJ, Salk JE and Lyles MA (2001) Absorptive capacity, learning, and performance in international joint ventures, Strategic Management Journal 22:1139-1161.

Laursen K and Foss NJ (2003) New human resource management practices, complementarities and the impact on innovation performance, Cambridge Journal of economics 27:243-263.

Lepak DP and Snell SA (1999) The human resource architecture: Toward a theory of human capital allocation and development, Academy of Management Review 24:31-48.

Lewin AY, Massini S and Peeters C (2011) Microfoundations of internal and external absorptive capacity routines, Organization Science 22:81-98.

Lichtenthaler U (2009) Absorptive capacity, environmental turbulence, and the complementarity of organizational learning processes, The Academy of Management Journal 52:822-846.

Minbaeva D, Foss N and Snell SA (2009) Bringing the knowledge perspective into HRM, Human Resource Management 48:477-483.

Minbaeva D, Pedersen T, Bjorkman I, Fey CF and Park HJ (2003) MNC knowledge transfer, subsidiary absorptive capacity, and HRM, Journal of International Business Studies 34:586-599.

Minbaeva DB (2005) HRM practices and MNC knowledge transfer, Personnel Review 34:125-144.

Podsakoff PM and Organ DW (1986) Self-report in organizational research: Problems and prospects, Journal of Management 12: 533-544.

Ravichandran T and Lertwongsatien C (2005) Effect of information systems resources and capabilities on firm performance: A resource-based perspective, Journal of Management Information Systems 21: 237-276.

Ringle C, Wende S and Will A (2005) Smart-PLS Version 2.0 M2, Hamburg: www.smartpls.de.

Simonin BL and Özsomer A (2009) Knowledge processes and learning outcomes in MNCs: an empirical investigation of the role of HRM practices in foreign subsidiaries, Human Resource Management 48:505-530.

Subramaniam M and Youndt MA (2005) The influence of intellectual capital on the types of innovative capabilities, The Academy of Management Journal 48:450-463.

Szulanski G (1996) Exploring internal stickiness: impediments to the transfer of best practice within the firm, Strategic Management Journal 17:27-43.

Tenenhaus M, Vinzi VE, Chatelin YM and Lauro C (2005) PLS path modelling, Computational Statistics \& Data Analysis 48:159 - 205.

Tsai W (2001) Knowledge transfer in intraorganizational networks: Effects of network position and absorptive capacity on business unit innovation and performance Academy of Management Journal, 44:996-1004.

Youndt MA and Snell SA (2004) Human resource configurations, intellectual capital, and organizational performance, Journal of Managerial Issues 16:337-360.

Youndt MA, Subramaniam M and Snell SA (2004) Intellectual capital profiles: An examination of 
investments and returns, Journal of Management Studies 41:335-361.

Zahra SA and George G (2002) Absorptive capacity: A review, reconceptualization, and extension, Academy of Management Review 27:185-203. 
Figure 1: Proposed Path Model

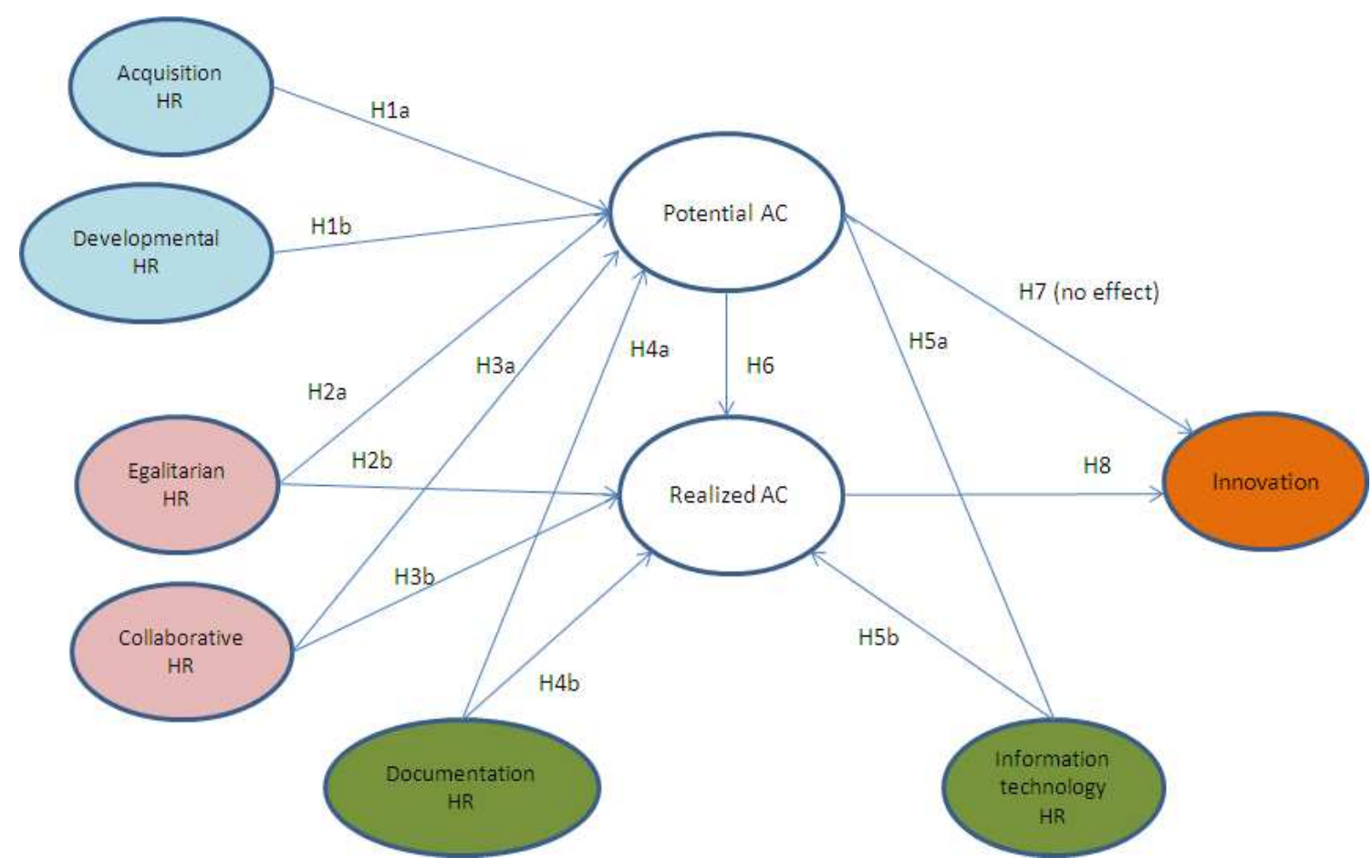


Table 1: List of Measurement Items

\begin{tabular}{|c|c|c|c|}
\hline \multicolumn{2}{|c|}{ Constructs } & Items & Alpha \\
\hline \multicolumn{4}{|c|}{ HR POLICIES AND PRACTICES } \\
\hline \multirow{6}{*}{ } & 1 & Our hiring process is thorough and comprehensive. & \multirow{6}{*}{0.65} \\
\hline & 2 & We screen many applicants to fill job openings. & \\
\hline & 3 & We use many different recruiting sources (i.e. agencies, universities, etc). & \\
\hline & 4 & We pay higher wages than our competitors. & \\
\hline & 5 & We focus on the candidate's potential to learn. & \\
\hline & 6 & We focus on the candidate's industry knowledge and experiences. & \\
\hline \multirow{11}{*}{ 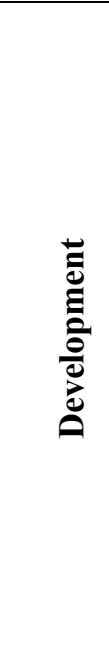 } & 1 & We spend more money per employee on training than our competitors. & \multirow{11}{*}{0.85} \\
\hline & 2 & Our employees spend more hours a year training than our competitors & \\
\hline & 3 & We provide continuous developmental opportunities to our employees. & \\
\hline & 4 & Our training and development activities are comprehensive. & \\
\hline & 5 & We offer many different types of training programs. & \\
\hline & 6 & $\begin{array}{l}\text { Our performance appraisal process tolerates mistakes that are non- } \\
\text { repetitive. }\end{array}$ & \\
\hline & 7 & Our employees receive a lot of developmental feedback. & \\
\hline & 8 & We try to promote from within. & \\
\hline & 9 & Our employees are rewarded for their knowledge/skill development. & \\
\hline & 10 & $\begin{array}{l}\text { Our training and development activities strive to develop firm-specific } \\
\text { skills/knowledge. }\end{array}$ & \\
\hline & 11 & $\begin{array}{l}\text { Our training and development activities emphasise on the job experiences } \\
\text { (on-the-job training). }\end{array}$ & \\
\hline \multirow{5}{*}{ 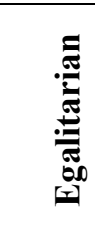 } & 1 & We try to eliminate and minimise status symbols & \multirow{5}{*}{0.78} \\
\hline & 2 & Our organisational structure minimises the number of hierarchical levels & \\
\hline & 3 & Our jobs encourage empowerment and participation & \\
\hline & 4 & We have few job classifications & \\
\hline & 5 & We have a narrow range of pay grades & \\
\hline \multirow{10}{*}{ 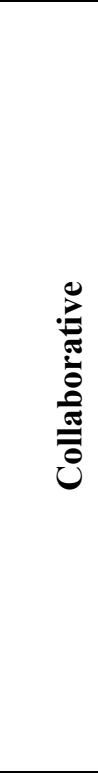 } & 1 & We select job candidates based on their interpersonal skills. & \multirow{10}{*}{0.78} \\
\hline & 2 & $\begin{array}{l}\text { We select job candidates based on their ability to collaborate and work in } \\
\text { teams. }\end{array}$ & \\
\hline & 3 & Our training and development incorporate team building. & \\
\hline & 4 & $\begin{array}{l}\text { Our performance appraisal system uses multiple inputs (i.e. peers, } \\
\text { customers, subordinates, etc.) }\end{array}$ & \\
\hline & 5 & We utilise group-based incentives (gainsharing, group bonuses, etc.) & \\
\hline & 6 & Our employees perform jobs that involve a lot of teamwork. & \\
\hline & 7 & $\begin{array}{l}\text { Our employees perform jobs that require them to participate in cross- } \\
\text { functional teams and networks. }\end{array}$ & \\
\hline & 8 & $\begin{array}{l}\text { Our employees perform jobs that require them to participate in employee- } \\
\text { customer teams and networks. }\end{array}$ & \\
\hline & 9 & $\begin{array}{l}\text { Performance appraisal for our employees acknowledge their ability to } \\
\text { work with others }\end{array}$ & \\
\hline & 10 & $\begin{array}{l}\text { Incentives /rewards for employees acknowledges their contribution } \\
\text { towards the learning of others (i.e. teaching, coaching or mentoring } \\
\text { others) }\end{array}$ & \\
\hline
\end{tabular}




\begin{tabular}{|c|c|c|c|}
\hline 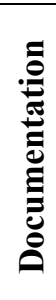 & $\begin{array}{l}2 \\
3\end{array}$ & $\begin{array}{l}\text { We encourage employees to write "lessons learned" reports from learning } \\
\text { experience (i.e. employee exchange programs, projects, etc) } \\
\text { We have a successful employee suggestion program } \\
\text { We encourage employees to continuously update our organisation's } \\
\text { [company's] knowledge databases } \\
\text { We encourage employees to suggest and share ideas on how to redesign } \\
\text { our work system. }\end{array}$ & 0.81 \\
\hline \multirow{7}{*}{ : } & 1 & Our information systems are user-friendly & \multirow{7}{*}{0.87} \\
\hline & 2 & Our information systems are accessible to all employees & \\
\hline & 3 & Our information systems are integrated with each other & \\
\hline & 4 & $\begin{array}{l}\text { The capacity of our information systems adequately meets our current } \\
\text { business needs }\end{array}$ & \\
\hline & 5 & $\begin{array}{l}\text { The information systems are continuously improved according to users' } \\
\text { feedback }\end{array}$ & \\
\hline & 6 & $\begin{array}{l}\text { Our training and development activities include how to use our } \\
\text { information systems effectively }\end{array}$ & \\
\hline & 7 & $\begin{array}{l}\text { Our information systems are designed to facilitate corporate data to be } \\
\text { shared across business units or departments }\end{array}$ & \\
\hline
\end{tabular}

1 We regularly collect industry information through informal means (e.g., lunch with industry friends, talks with trade partners)

2 We regularly scan the external environment for new information, knowledge or technologies

3 It is common for our employees to approach customers, suppliers or third parties (i.e. consultants, financial advisors, etc) to acquire new knowledge

4 The search for relevant information concerning our industry is every-day business in our organisation

5 We keep ourselves constantly updated with the latest technologies or state of the art knowledge related to our organisation's business

1 Our employees quickly recognise and understand the usefulness of new external knowledge

2 We quickly analyse and interpret the impact of changing market demands

3 New opportunities to serve our customers are quickly understood

4 We are slow to recognise and interpret shifts in our market (e.g., competition, regulation, demography)

5 In our organisation, new external information or knowledge is quickly communicated across all business units or departments

6 Our management demands periodical cross-departmental meetings to exchange and analyse new knowledge or technological developments from the external environment

1 Our employees record and store newly acquired knowledge for future reference

2 Our employees have the ability to successfully link existing knowledge with new knowledge or insights

3 Our employees regularly meet to discuss how to utilise new knowledge to improve our current products, services or internal processes

4 Our employees are able to apply new knowledge in their practical work

5 In this organisation, we regularly consider the consequences of changing market demands in terms of new (or improved) products and/or services 
6 In this organisation, we periodically meets to discuss consequences of market trends and new product development

1 Our management supports the development of prototypes, new products, services or processes

2 Our organisation regularly reconsiders our current products, services or processes and adapts them in accordance with new knowledge or technologies

3 Our organisation has the ability to work more effectively by adopting new technologies or knowledge

4 We regularly implement new technologies to develop new products, services or processes

5 In this organisation, we are proficient in transforming new knowledge into new (or improved)products, services or processes

6 We regularly consider how to better exploit knowledge and/or technologies

Our organisation has difficulty implementing new products and services

\section{INNOVATION PERFORMANCE}

In the last 3 years, to what extent did your organisation introduce new products/services and processes that

\begin{tabular}{|c|c|c|c|}
\hline \multirow{5}{*}{ 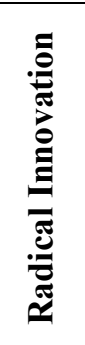 } & 1 & Involved fundamentally new concepts or principles for the organisation. & \multirow{5}{*}{0.94} \\
\hline & 2 & Required new skills which the organisation did not possess & \\
\hline & $\begin{array}{l}3 \\
4\end{array}$ & $\begin{array}{l}\text { Required the organisation to develop many new skills } \\
\text { Required the organisation to learn from completely new or different } \\
\text { knowled5e bases }\end{array}$ & \\
\hline & 5 & Required the organisation to adopt different methods and procedures & \\
\hline & 6 & Required the organisation to carry out a great deal of retraining & \\
\hline \multirow{6}{*}{ 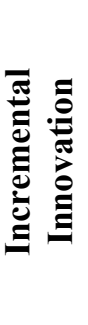 } & 1 & Required simple adjustments to existing technologies & \multirow{6}{*}{0.68} \\
\hline & 2 & Built a great deal on the organisation's prior skills & \\
\hline & 3 & Built heavily on the organisation's existing experience base & \\
\hline & 4 & Built heavily on the organisation's existing knowledge & \\
\hline & 5 & Rendered the organisation's experience base obsolete & \\
\hline & 6 & $\begin{array}{l}\text { Rendered obsolete the expertise that was required to master the older } \\
\text { products/services/processes }\end{array}$ & \\
\hline
\end{tabular}


Table 2: Descriptive Statistics, AVEs, and Intercorrelations

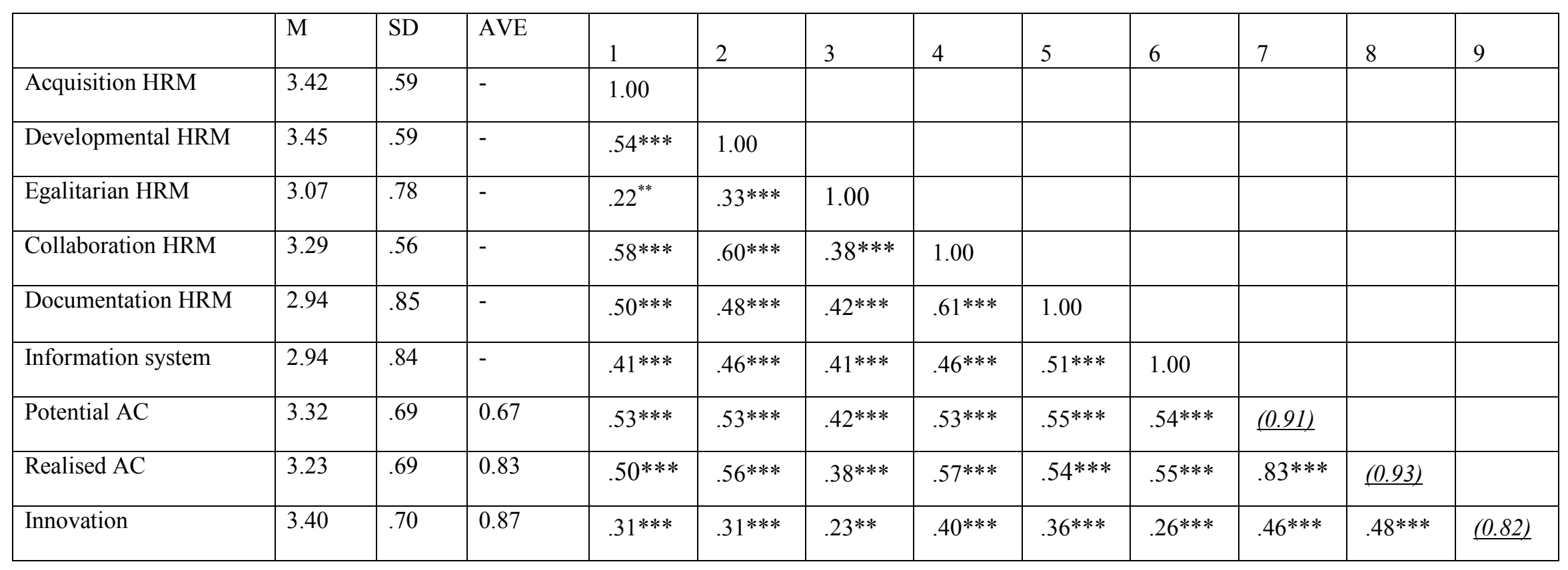

$\mathrm{N}=221$

$* \mathrm{p}<.05 ; * * \mathrm{p}<.01 ; * * * \mathrm{P}<.001$

Square root of average variance estimates (AVEs) are reported as italicised and underlined in order to show evidence of Fornell and Larcker's (1981) test. 
Table 3: Results of Path Analysis

\begin{tabular}{|l|l|l|l|}
\hline Paths & Coefficients & t-statistic & Sig. level \\
\hline Acquisition HR $\rightarrow$ Potential AC & 0.20 & 3.00 & $* *$ \\
\hline Developmental HR -> Potential AC & 0.17 & 2.21 & $*$ \\
\hline Egalitarian HR -> Potential AC & 0.14 & 2.04 & $*$ \\
\hline Egalitarian HR -> Realised AC & -0.02 & 0.57 & n.s. \\
\hline Collaborative HR -> Potential AC & 0.07 & 0.99 & n.s. \\
\hline Collaborative HR -> Realised AC & 0.15 & 2.70 & $* *$ \\
\hline Documentation HR -> Potential AC & 0.16 & 2.13 & $*$ \\
\hline Documentation HR -> Realised AC & 0.02 & 0.43 & n.s. \\
\hline IT HR -> Potential AC & 0.21 & 3.72 & $* * *$ \\
\hline IT HR -> Realised AC & 0.11 & 2.50 & $*$ \\
\hline Potential AC -> Realised AC & 0.70 & 17.96 & $* * *$ \\
\hline Potential AC -> Innovation Performance & 0.18 & 1.89 & n.s. \\
\hline Realised AC -> Innovation Performance & 0.34 & 3.40 & $* * *$ \\
\hline
\end{tabular}

$\mathrm{N}=221$

n.s. not significant

${ }^{*} \mathrm{p}<.05, * * \mathrm{p}<.01 ; * * * \mathrm{p}<.001$ 